\title{
GROWTH PARAMETERS AND MORTALITY RATE OF THE SCOMBER JAPONICUS PERUANUS (JORDÁN \& HUBB, 1925) ALONG THE PERUVIAN COAST, SOUTH PACIFIC
}

\author{
Hilda Caramantin-Soriano ${ }^{1}$; Luz Amelia Vega-Pérez ${ }^{1}$ and Miguel Ñiquen $^{2}$ \\ ${ }^{1}$ Instituto Oceanográfico da Universidade de São Paulo \\ (Praça do Oceanográfico, 191, 05508-120 São Paulo, SP, Brasil) \\ ${ }^{2}$ Instituto del Mar del Perú \\ (Apartado Postal 22 Callao, Perú)
}

Corresponding authors: hildacs@hotmail.com; lavega@usp.br

\section{A B S T R A C T}

\begin{abstract}
The growth parameters and the mortality rates of the Scomber japonicus peruanus (Chub mackerel) were studied based on monthly data of frequency of fork length classes obtained from commercial landings off the Peruvian coast from 1996 to 1998 . The asymptotic body length and growth rate values obtained by the ELEFAN I (Electronic Length Frequency Analysis) ranged from $40.20 \mathrm{~cm}$ to $42.20 \mathrm{~cm}$ and from 0.38 to 0.39 , respectively. The oscillation amplitude was 0.60 ; the Winter point values varied from 0.50 to 0.60 and the performance index from 2.79 to 2.84 . The total mortality rate of the Chub mackerel obtained by the linearized catch curve oscillated between 1.68 and 3.35. The rate of fishing mortality varied from 1.16 to 2.78 and the exploitation rate from 0.68 to 0.84 . The annual rate of natural mortality estimated by the Pauly's method ranged from 0.52 to 0.53 . The results obtained allow us to conclude that the longevity of the Chub mackerel was slightly over seven years.
\end{abstract}

\section{R E S UMO}

Os parâmetros de crescimento e as taxas de mortalidade de Scomber japonicus peruanus (cavalinha) foram estudados a partir de dados mensais de freqüência de classes de comprimento provenientes do desembarque comercial ao longo da costa peruana no período de 1996 a 1998. Os valores do comprimento furcal assintótico e da taxa de crescimento obtido pelo ELEFAN I(Electronic Length Frequency Analysis) variaram de $40,20 \mathrm{~cm}$ a $42,20 \mathrm{~cm}$ e de 0,38 a 0,39 , respectivamente. A amplitude de oscilação foi de 0,60 ; os valores de Winter point variaram de 0,5 a 0,6 e os do índice de performance entre 2,79 e 2,84 . As taxas de mortalidade total da cavalinha obtidas pela análise da curva de captura linearizada oscilaram entre 1,68 e 3,35, sendo as variações das taxas de mortalidade por pesca e explotação de 1,16 a 2,78 e 0,68 a 0,84 , respectivamente. A taxa anual de mortalidade natural estimada pelo método de Pauly variou de 0,52 a 0,53 . Os resultados obtidos permitem inferir que a longevidade da cavalinha foi de pouco mais de sete anos.

Descriptors: Scombridae, Chub mackerel, Growth, Mortality rate, South-Pacific.

Descritores: Scombridae, Cavalinha; Crescimento; Taxa de mortalidade, Pacífico Sul.

\section{INTRODUCTION}

Studies of age, growth, mortality rate and exploitation rate are crucial for stock assessment (DULCIC et al., 2007). The growth parameters and the mortality rate are important tools to assessment the exploitation level of the pelagic species (CADIMA, 2000). However, fish stock assessment should be carried out for each stock separately, since an essential characteristic of a stock is that its population parameters remain constant throughout its area of distribution (KAMUKURU et al., 2005; WANG; LIU, 2006). Scomber japonicus peruanus "Chub mackerel" is a coastal pelagic species of the Scombridae family

$\overline{\text { Contr. No. } 876}$ do Inst. oceanogr. da Usp. that has a wide distribution in the South Pacific Ocean, especially in the coastal waters of Costa Rica, Peru, Chile and Equator, including the Galapagos Island (CHIRICHIGNO; VÉLEZ, 1998).

The distribution of the Chub mackerel in the Peruvian sea is associated with Equatorial Surface Water (DIOSES et al., 2002), being their main spawning ground located to the northern-central region (SANTANDER; FLORES, 1983, CARAMANTÍN, 2001). This species is considered one of the most important fishery resources for the Peruvian economy (IMARPE \& ITP, 1996). However, in spite of its widespread occurrence in the Peruvian waters and economic importance, very little is known about the dynamic population of $S$. japonicus peruanus. There are also few studies on growth and mortality of this 
species from off the Peruvian coast (MIÑANO; CASTILLO, 1971; MENDO, 1984; CARAMANTÍN, 2006).

The purpose of this study was to provide information on growth parameters and the mortality rate of $S$. japonicus peruanus along the Peruvian coast from 1996 to 1998.

\section{Material and Methods}

The growth parameters and the mortality rates of the $S$. japonicus peruanus (Chub mackerel) were studied based on monthly data of frequency of fork length classes obtained from commercial landings along the Peruvian coast $\left(3^{\circ} 23^{\prime} \mathrm{S}-18^{\circ} 20^{\prime} \mathrm{S}\right.$ and $72^{\circ} \mathrm{W}-$ $84^{\circ} \mathrm{W}$ ) from 1996 to 1998 , within the project "Tracking of pelagic resources off the Peruvian coast", which is being carried out at the "Instituto del Mar del Perú - IMARPE" (Fig. 1). The Sea Surface Temperature (SST) was recorded in situ at each one of the sampling areas with a bucket thermometer.

The specimens were caught with industrial purse seine vessel, using mesh sizes of $38 \mathrm{~mm}$. Each time, a random sample of around $40 \mathrm{~kg}$ was taken from a vessel before the catch was sorted and landed. The fork length of each individual was measured to the nearest $\mathrm{cm}$ and pooled in $1 \mathrm{~cm}$ length classes.
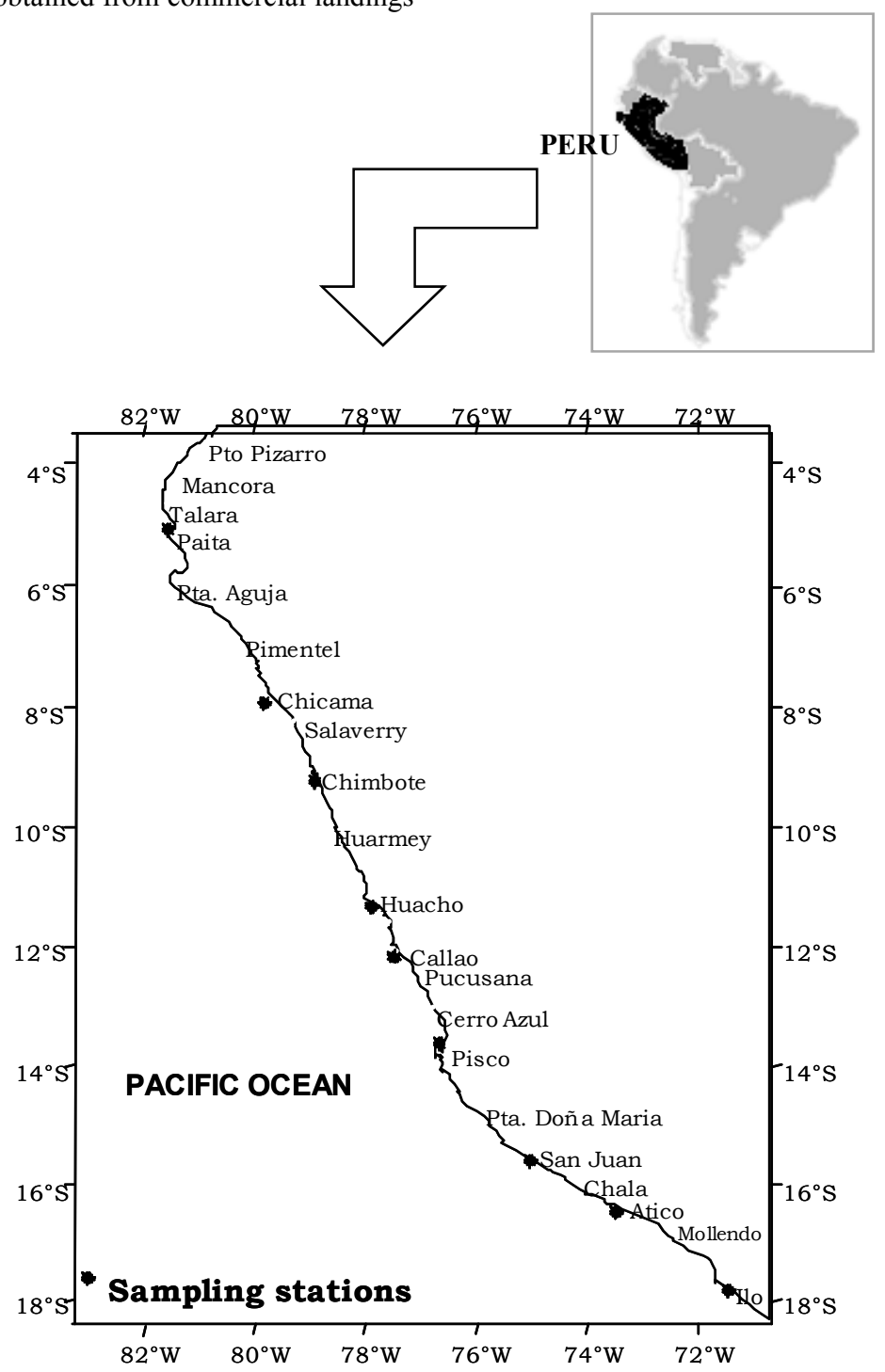

Fig. 1. Location of sampling stations along the Peruvian coast. 
The length frequency samples were raised to monthly catch for each sampling area which were summed to account for the total length frequency distribution of the month for the entire area.

The growth rate $(K)$ and the asymptotic length fork $\left(L f_{\infty}\right)$ were estimated using the ELEFAN I method (Electronic Length Frequency Analysis), which estimated the parameters of the von Bertalanffy growth curve as a function of the seasonality (PAULY; GASCHUTZ, 1979):

$L f=L f_{\infty}\left\{1-\exp \left[-K .(t-t o)-\left(\frac{C K}{2 \pi}\right) .(\operatorname{sen} 2 \pi \cdot(t-t s))\right]\right\}$

where: $L f_{\infty}=$ asymptotic fork length; $K=$ growth rate; $t_{o}=$ theoretical age of fish at zero length; $C=$ growth oscillation "amplitude", related with environmental temperature of winter and summer; Winter point $(W p)$ $=$ period of the year where the fish growth is lowest.

The theoretical age at which the fish has mean length zero $\left(t_{o}\right)$ was estimated by Pauly's (1979) formula:

$\log \left(-t_{o}\right)=-0.392-0.275 \log . L f_{\infty}-1.038 \log K$

The Index of growth performance $(\phi)$ (PAULY; MUNRO, 1984) was calculated using the following equation: $\phi=\log K+2 \log L f_{\infty}$; where: $L f_{\infty}$ and $K$ are the growth parameters of the von Bertalanffy equation.

The total mortality $(Z)$ was estimated by means of the catch curve based on fork length frequency class, converted into age groups, and the growth parameters $\mathrm{Lf}_{\infty}$ and $\mathrm{K}$ of von Bertalanffy's curve (SPARRE; VENEMA, 1997). The equation utilized was:

$\operatorname{Ln} C \frac{\left(L f_{1}, L f_{2}\right)}{\Delta t\left(L f_{1}, L f_{2}\right)}=C-Z t \frac{\left(L f_{1}+L f_{2}\right)}{2}$

where: $C$ is the number of the specimens caught in determined length range; $Z$ is the total mortality and $\Delta t$ the mean time in which the fish grows since the fork length $L f_{1}$ to $L f_{2}$.

The natural mortality $(M)$ was estimated using the Pauly's (1980) empiric formula: $M=0.8 \exp$ [-0.0152 - 0.0279 Ln Lf $\left.f_{\infty}+0.6543 L n K+0.463 \ln T\right]$; where: $T$ is the annual mean water temperature value, which was $17^{\circ} \mathrm{C}$ for the given sampling area.

Fishing mortality $(F)$ was estimated from the difference between the total mortality $(Z)$ and the natural mortality $(M)$. The exploitation rate $(E)$ was calculated as a function of: $E=F / Z$ (SPARRE; VENEMA, 1997).

The Chub mackerel longevity was obtained using the Pauly and Munro (1984) equation: $T_{\max } .=$ $3 / K$; where $K$ is the growth rate.

\section{RESULTS}

The Sea Surface Temperatures (SST) recorded during the period of the study ranged from 16.06 (1996) to $25.90^{\circ} \mathrm{C}$ (1998), being higher in June and December 1997 and January-April 1998, and lowest in June-October 1996 and SeptemberNovember 1998. Similar values of SST were registered in January-February 1996 and 1997 (Fig. 2).

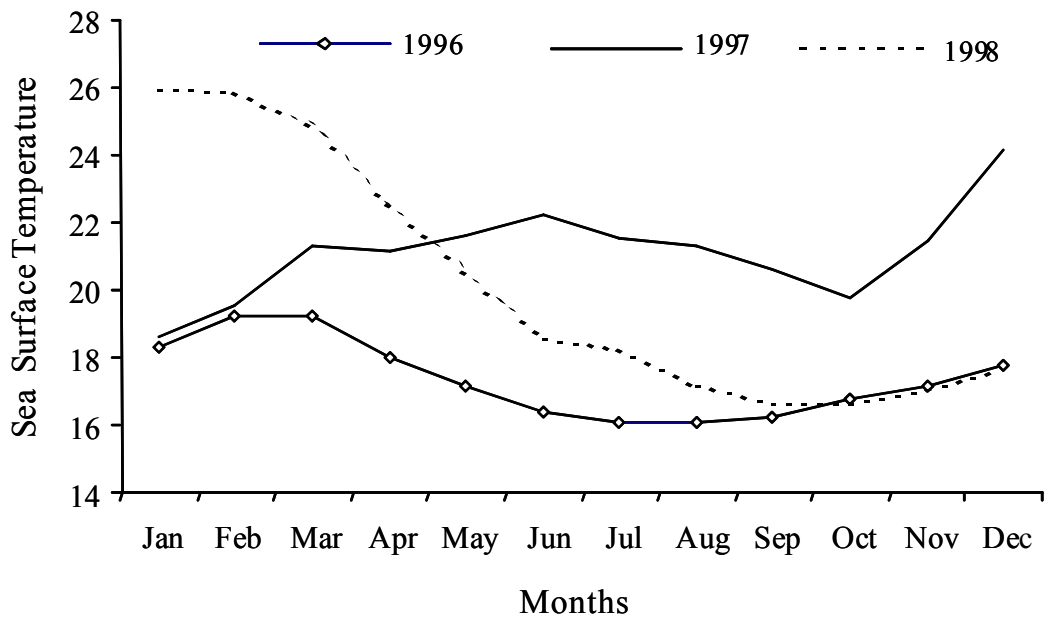

Fig. 2. Monthly values of the Sea Surface Temperature in the Peruvian coast from 1996 to 1998. 
A total of 3363361 specimens of $S$. japonicus peruanus, ranging from $10 \mathrm{~cm}$ to $39 \mathrm{~cm} F L$ were collected between January 1996 and December 1998 (Table 1).

The values of the asymptotic length $\left(L f_{\infty}\right)$ and the growth rate $(K)$ varied from $40.20 \mathrm{~cm}$ to 42.20 $\mathrm{cm}$, and from 0.38 to 0.39 , respectively. The results obtained showed that the oscillation amplitude was
0.60 . The Winter point values varied between 0.5 and 0.6 , whereas the performance index ranged from 2.79 to 2.84 (Table 2).

The growth curves indicated the presence of seven complete cohorts and one cohort constituted by a few months. Assuming that each cohort corresponds to one year old, it is possible to suggest that the Chub mackerel longevity is slightly over 7 years (Fig. 3).

Tabela 1. Monthly catch at fork length class values of S. japonicus peruanus from 1996 to 1998.

\begin{tabular}{|c|c|c|c|c|c|c|c|c|c|c|c|c|}
\hline Length class & Jan & Feb & Mar & Apr & May & Jun & Jul & Aug & Sep & Oct & Nov & Dec \\
\hline 10 & & & & & & & & 38 & & 22 & 58 & \\
\hline 11 & & & & & & & & 153 & & 136 & 360 & 2 \\
\hline 12 & & & & & & & & 115 & 11 & 460 & 1092 & 33 \\
\hline 13 & & & & & & & & 38 & 11 & 2325 & 2717 & 201 \\
\hline 14 & & & & & & 1 & 2 & 0 & 11 & 2765 & 4704 & 282 \\
\hline 15 & & 1 & 5 & & & 22 & 26 & 73 & 11 & 1440 & 9104 & 466 \\
\hline 16 & 3 & 149 & 12 & 2 & 42 & 3 & 93 & 174 & 404 & 352 & 7185 & 942 \\
\hline 17 & 2062 & 208 & 86 & 11 & 1092 & 1508 & 62 & 423 & 96 & 244 & 7487 & 1592 \\
\hline 18 & 3993 & 442 & 322 & 40 & 539 & 1596 & 189 & 530 & 259 & 361 & 4861 & 3314 \\
\hline 19 & 85 & 936 & 486 & 50 & 600 & 1835 & 548 & 396 & 310 & 606 & 2785 & 4640 \\
\hline 20 & 728 & 1045 & 299 & 27 & 332 & 1121 & 793 & 789 & 1186 & 1323 & 2969 & 6756 \\
\hline 21 & 2072 & 1165 & 96 & 34 & 674 & 1129 & 959 & 1159 & 3003 & 2694 & 6165 & 11675 \\
\hline 22 & 1419 & 1368 & 37 & 166 & 431 & 1298 & 933 & 757 & 4679 & 3252 & 16416 & 15139 \\
\hline 23 & 1983 & 831 & 168 & 741 & 464 & 674 & 2388 & 963 & 2936 & 3619 & 13261 & 25265 \\
\hline 24 & 5288 & 2057 & 672 & 3229 & 591 & 982 & 3772 & 2576 & 4929 & 5825 & 11087 & 24553 \\
\hline 25 & 2546 & 7712 & 2017 & 4407 & 913 & 2584 & 7258 & 9845 & 9614 & 9595 & 93675 & 31315 \\
\hline 26 & 12713 & 38205 & 7164 & 5837 & 3893 & 4602 & 10527 & 22769 & 24963 & 23622 & 82752 & 46468 \\
\hline 27 & 96081 & 75009 & 10091 & 6268 & 9118 & 6873 & 12204 & 36998 & 49405 & 47288 & 93518 & 88572 \\
\hline 28 & 115092 & 72457 & 8727 & 5083 & 11951 & 9107 & 10593 & 40358 & 62284 & 60587 & 173766 & 146703 \\
\hline 29 & 59537 & 45393 & 4101 & 4306 & 8537 & 5482 & 4897 & 33831 & 48303 & 63029 & 217537 & 93492 \\
\hline 30 & 20402 & 22090 & 1597 & 2596 & 4283 & 2062 & 1666 & 18177 & 25614 & 36638 & 252073 & 52592 \\
\hline 31 & 5418 & 11547 & 683 & 1390 & 2225 & 1358 & 1335 & 10858 & 13970 & 16993 & 78006 & 19460 \\
\hline 32 & 2660 & 7290 & 470 & 897 & 1135 & 1311 & 614 & 6290 & 9879 & 11083 & 49984 & 10995 \\
\hline 33 & 1510 & 3678 & 243 & 410 & 628 & 619 & 140 & 3576 & 5562 & 5047 & 18644 & 3378 \\
\hline 34 & 359 & 1322 & 125 & 118 & 198 & 172 & 77 & 1483 & 2142 & 2187 & 2113 & 2879 \\
\hline 35 & 60 & 538 & 39 & 24 & 18 & 98 & 35 & 400 & 869 & 749 & 425 & 83 \\
\hline 36 & 51 & 267 & 7 & & & 19 & & 43 & 519 & 482 & 388 & 21 \\
\hline 37 & 111 & 69 & & & & & & & 117 & 125 & 67 & 38 \\
\hline 38 & 60 & 3 & & & & & & & 33 & 45 & 5 & \\
\hline 39 & 15 & 7 & 7 & & & & & & 22 & & 90 & \\
\hline Total & 334247 & 293789 & 37453 & 35636 & 47663 & 44458 & 59111 & 192814 & 271141 & 302896 & 1153296 & 590856 \\
\hline $\begin{array}{l}\text { Standard } \\
\text { deviation }\end{array}$ & 70873 & 60435 & 8015 & 7700 & 10445 & 9329 & 12855 & 41233 & 54839 & 62274 & 232353 & 123347 \\
\hline
\end{tabular}


Table 2. Growth parameters of S. japonicus peruanus obtained by ELEFAN I method from 1996 to 1998 . Asymptotic fork length $\left(L f_{\infty}\right)$; growth rate $(\mathrm{K})$; growth oscillation Amplitude $(\mathrm{C})$; Winter point $(\mathrm{Wp})$; growth performance index $(\phi)$; sample size $(\mathrm{n})$.

\begin{tabular}{|c|c|c|c|c|c|c|}
\hline Years & $L f_{\infty}$ & $K$ & $C$ & $W p$ & $\phi$ & Sample size \\
\hline 1996 & 40.20 & 0.38 & 0.60 & 0.60 & 2.79 & $\mathrm{n}=178067$ \\
\hline 1997 & 42.20 & 0.39 & 0.60 & 0.50 & 2.84 & $\mathrm{n}=720608$ \\
\hline 1998 & 41.50 & 0.39 & 0.60 & 0.5 & 2.83 & $\mathrm{n}=2464686$ \\
\hline Mean & 41.30 & 0.39 & 0.60 & 0.53 & 2.82 & $\mathrm{n}=3363.361$ \\
\hline Standard Deviation & 1.01 & 0.01 & 0.00 & 0.06 & 0.03 & \\
\hline
\end{tabular}

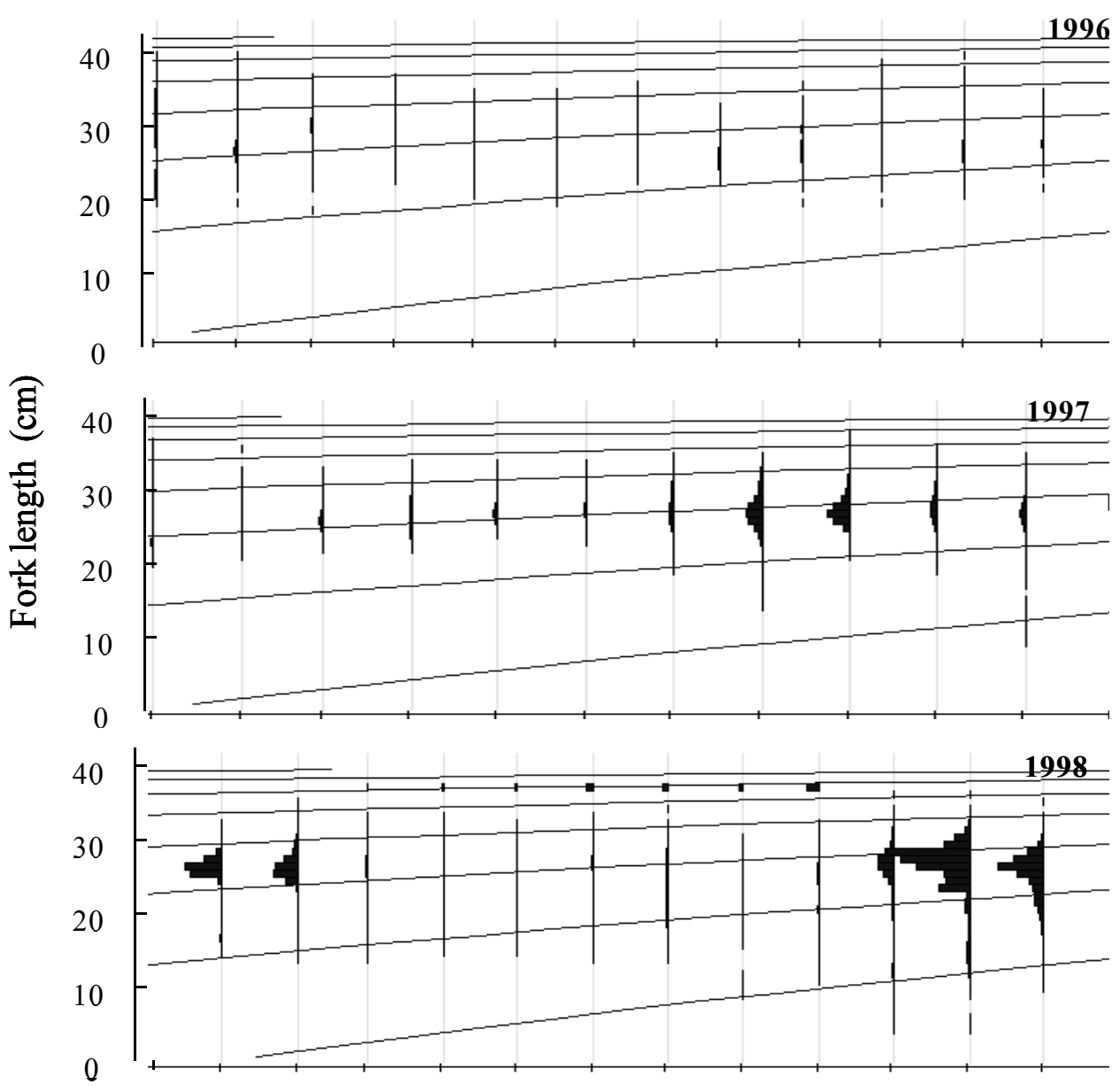

Jan Feb Mar Apr May Jun Jul Aug Sep Oct Nov Dec

Fig. 3. Growth curves of $S$. japonicus peruanus estimated by ELEFAN I method from 1996 to 1998. 
During the study period 1996-1998, the age at which the Chub mackerel had length zero $\left(t_{o}\right)$ was 0.39 year to -0.40 year (Table 3 ). The results also showed that the total mortality of the species obtained from the linearized catch curve ranged from 1.68 to 3.35 , being the mean value 2.53 (Table 4). However, the natural mortality annual rate $(M)$ estimated by Pauly's empiric formula oscillated between 0.52 and 0.53 (Table 4).

The fishing mortality rate $(F)$ of the Chub mackerel estimated on annual basis, varied from 1.16 to 2.78 , being the mean value 2 . In contrast, the exploitation rate $(E)$ ranged from 0.68 to 0.84 , with mean value 0.77 (Table 4).

The mean longevity of the Chub mackerel estimated by Pauly's method from the period 1996 to 1998 was 7.77 years (Table 4).

Table 3. Theoretical annual age values at length zero (to) of S. japonicus peruanus from 1996 to 1998 .

\begin{tabular}{lc}
\hline \hline \multicolumn{1}{c}{ Years } & $t_{o}$ \\
\hline 1996 & -0.40 \\
1997 & -0.39 \\
1998 & -0.39 \\
Mean & -0.39 \\
Standard Deviation & 0.01 \\
\hline
\end{tabular}

Table 4. Total annual $(Z)$, natural $(M)$, fishing $(F)$ exploitation $(E)$ mortality rates and longevity of $S$. japonicus peruanus from 1996 to 1998.

\begin{tabular}{lccccc}
\hline \hline Years & $Z$ & $M$ & $F$ & $E$ & Longevity \\
\hline 1996 & 1.68 & 0.52 & 1.16 & 0.68 & 7.90 \\
1997 & 2.56 & 0.52 & 2.13 & 0.80 & 7.70 \\
1998 & 3.35 & 0.53 & 2.78 & 0.84 & 7.70 \\
Mean & 2.53 & 0.52 & 2.00 & 0.77 & 7.77 \\
$\begin{array}{l}\text { Standard } \\
\text { Deviation }\end{array}$ & 0.84 & 0.01 & 0.82 & 0.08 & 0.12 \\
\hline
\end{tabular}

\section{DisCuSSÃo}

Growth is an increase of body size resulting from production of new tissues. This process during a particular period result in formation of growth marks on hard parts of the fish species: scales, opercula bones, spines, vertebrae, teeth and otoliths (BERTALANFFY, 1957; BEAMISH; MCFARLANE, 1983; CAMPANA, 2001; MANCERA-RODRÍGUEZ; CASTRO-HERNÁNDEZ, 2004). The body size is an important variable in fisheries ecology as it provides a basis for predicting life history features, including maturity, longevity and mortality rates (FROESE; PAULY, 2000; CHOAT et al., 2006).

Growth or changes in size of fish can be best evaluated on rate basis, therefore, a temporal measurement such as age is essential in growth studies. Age data can usually be obtained by counting annual increments of hard part caused by the response of the fish to strong fluctuations in environmental conditions. In warmer areas, such changes are less pronounced and it is therefore difficult to use a seasonal ring for age determination (SPARRE; VENEMA, 1997). In this case, the analysis of lengthfrequency data has been widely used for tracing the survival and growth of fish by identifying cohorts or age groups (BHATTACHARYA, 1967; PEREIRO, 1992).

The utility of length frequency analysis for age determination compared to other methods using hard structures is a contentious issue (HILBORN; WALTERS, 1992). Although, length frequency analysis method is of widespread use at the present time, some studies did not fulfill its requirements (CAMPANA, 2001). Iversen (1996) mentioned some limitations about length-frequency methods for age determination such as "....The method should be used for relatively short time spawning season fishes, the technique requires big samples with wide size range and the age at first capture should be known to detect the age of first modal group. Nevertheless, it was possible to mitigate some limitations in this study, since the analyzed samples were representative and was possible to separate efficiently the overlapping of length modes".Physical environment is an essential factor in regulating marine fish populations (CUSHING, 1982). In general, growth may be influenced by several factors such as density, temperature, salinity, reproductive cycle and food availability (FREÓN; MISUND, 1999; SWAIN et al., 2003; LAPPALAINEN et al., 2005; DULCIC et al., CARAMANTÍN-SORIANO ET AL: GROWTH PARAMETERS AND MORTALITY RATE 2007). Temperature is one of the factors influencing the metabolism, growth and natural mortality of several fish species (PAULY, 1980; MARTINEZ-PALACIOS et al., 1996; ROBARDS et al., 2002; WILLIAMS et al., 2007). It has been reported that the sea water temperature also affect the recruitment and, hence, fish stock abundance (CARDINALE; YELM, 2006).

In Argentinean sea waters, the growth of $S$. japonicus is influenced by the higher water temperature (PERROTA et al., 2001. These results 
coincide with that reported by Robards et al. (2002). However, extremely high or low temperatures can have negative effect on the growth and mortality of the first stage of life in S. japonicus (HWANG; LEE, 2005).

Remarkable variations of temperatures due to El Niño event may influence the annual growth rate of the pelagic species (PARRISH et al., 1985; ARNTZ; BERNAL, 1996). According to Kikkawa et al. (2001), the age and the growth rate of Thunnus obesus from the equatorial western Pacific Ocean was influenced during El Niño events. The results obtained in the present study did not show great variation in the growth parameters of $S$. japonicus peruanus during 1997-1998 El Niño events (Table 2), probably, due to the low variations of the catch composition at fork length obtained during that event.

In general, the seasonal growth of fish might be related to their life-cycle, spawning time, feeding regimes and the metabolic costs of different activities (PAULY, 1979; MOREAU, 1987; PAJUELO; LORENZO 2001). This seasonality of the growth in pelagic fishes has close relation with the growth parameters Winter point $(W p)$ and oscillation Amplitude (C), (PAULY; TSUKAYAMA, 1983; CUCALÓN-ZENCK, 1999; BELLIDO et al., 2000). According to Pauly and Tsukayama (1983), the values of the oscillation Amplitude are related with environmental temperature of winter and Summer, which appear to be related to reproduction and food abundance. Palomares et al. (1987) based on $W p(0.7)$ and $C(0.27)$ values obtained to Engraulis rigens from Peruvian coast concluded that their growth is slower in winter, when their main spawning peak is taking place.

The results obtained in the present study, revealed that the growth of $S$. japonicus peruanus was slower in summer by approximately $60 \%$ (Table 2 ) with respect to the average growth. Coincidentally, the reproductive activity of the species is more intense in this season of the year, since it has a partial spawner with a period of reproductive activity between August to March (MENDO, 1984; CARAMANTÍN,-SORIANO, 2001).

According to Perrota (1993) and Kiparissis et al. (2000) the growth of S. japonicus is relatively variable being their growth rate from 0.17 to 0.47 (MORALES-NIN, 1988; DAWSON, 1986; GLUYAS-MILLÁN;QUIÑONEZ-VELAZQUEZ, 1997; CUCALÓN-ZENCK, 1999).

Mendo (1984), based on otoliths analysis, concluded that in the Peruvian coast the asymptotic body length and growth rate of $S$. japonicus peruanus were 40.6 and 0.41 respectively. In the present study, the mean asymptotic body length (41.30) and growth rate $(0.39)$ of Chub mackerel from the same area agreed with data reported by that author.

Errors in the estimative of the growth fish parameters $\left(C f_{\infty}\right.$ e $\left.K\right)$ can be evaluated using the growth performance Index $(\phi)$ (PAULY; MUNRO, 1984).

According to Moreau et al. (1986), species within the same family are expected to have similar $\phi$ values. Cucalón-Zenck (1999), using fork length frequency data of $S$. japonicus peruanus from the Gulf of Equator from 1989 to 1996, obtained a mean performance Index of 2.95. The value of $\phi(2.82)$ found in the present study is a strong indication that the Chub mackerel of these two regions would belong to the same stock.

Aguayo and Steffens (1986), Dawson (1986), Menz and Pizarro (1988) and Cucalón-Zenck (1999) reported that the $\mathrm{L} f_{\infty}$ and $K$ values of $S$. japonicus peruanus, from the Equator and Chile regions, ranged from $38 \mathrm{~cm}$ to $45 \mathrm{~cm}$ and 0.16 to 0.41 , respectively (Table 5). The results obtained in the present study ( $\overline{\mathrm{L}} \mathrm{f}_{\infty}=41.30 \mathrm{~cm}$ and $\bar{K}=0.39$ ) are well within the range reported by various authors in other areas of the eastern Pacific (Table 5).

Table 5. Growth parameters of S. japonicus peruanus obtained by different authors.

\begin{tabular}{lcccc}
\hline \hline \multirow{2}{*}{ Authors } & \multicolumn{3}{c}{ Growth parameters } & \multirow{2}{*}{ Method/Area } \\
\hline Mendo (1984) & $L f_{\infty}$ & $K$ & $\phi$ & \\
Aguayo \& Steffens (1986) & 40.60 & 0.41 & 2.92 & Direct-Peru \\
Dawson (1986) & 44.40 & 0.16 & 2.58 & Direct-Chile \\
Menz \& Pizarro (1988) & 40.50 & 0.21 & 2.62 & Direct-Equador \\
Cucalón-Zenck (1999) & 38.00 & 0.41 & - & Indirect-Equador \\
Present study & 45.00 & 0.37 & 2.95 & Indirect-Equador \\
& $\mathbf{4 1 . 3 0}$ & $\mathbf{0 . 3 9}$ & $\mathbf{2 . 8 2}$ & Indirect-Peru \\
\hline
\end{tabular}


The values of total mortality rate, fishing and exploitation suggest that in those years $S$. japonicus peruanus was over-exploited and nearing its maximum capacity, since its mean exploitation rate was 0.77 . This may be confirmed by the fact that a remarkable increase in Chub mackarel abundance of juvenile has been observed (NIQUEN; BOUCHON, 2004; CARAMANTÍN, 2006).

In relation to the rate of natural mortality of $S$. japonicus peruanus in Peruvian waters, the results obtained (0.52) seem to confirm the findings of Oldepesca (1986) and Perrota (1993), who found for $S$. japonicus from Argentina and Equator sea values ranging from 0.40 to 0.54

The magnitude of $K$ has a direct relationship with the lon longevity of any fish (PAULY, 1980). This becomes obvious if we consider that the oldest fishes in a given exploited stock, in nature, generally reach about $95 \%$ of their asymptotic length (TAYLOR, 1958). Our findings suggested that the largest specimen of Chub mackerel found in the samples was probably the oldest fish, since that length $(C f=39 \mathrm{~cm})$ as mean asymptotic length $(C f=41.30$ $\mathrm{cm})$ were very close.

Gluyas-Millán and Quiñonez-Velázquez (1997) based on the analysis of the otholits concluded that the longevity of $S$. japonicus can reach up to 9 years in the Gulf of California, and 8 years in the Equator region (CUCALÓN-ZENCK, 1999). These conclusions are in accordance with our findings because the mean longevity of $S$. japonicus peruanus was 7.77 years.

The results obtained in the present study emphasize that the control of fish landings, better enforcement of legislation and continued monitoring in the coastal environment are very important and necessary for sustainable fisheries (FAO, 2007).

\section{ACKNOWLEDGEMENTS}

The first author is grateful to the National Council for the Development of Science and Technology $(\mathrm{CNPq})$ for the fellowships (Grant: Proc. $\mathrm{N}^{\mathrm{o}}$ 140023/03-8). The authors are grateful to the "Instituto del Mar del Peru - IMARPE" for making available the material for supporting this study and for the use of their laboratories. We also thank Katya P. Schinke for her help, and the two anonymous reviewers of this paper, whose remarks were extremely helpful.

\section{REFERENCES}

AGUAYO, M.; STEFFENS, H. Edad y crecimiento de Scomber japonicus peruanus del norte de Chile. Investigacion pesq., Santiago, v. 33, p. 61-73, 1986.
ARNTZ, W. E.; FAHRBACH, E. El Niño-Experimento climático de la naturaleza. Mexico: Fondo de Cultura Económica, 1996. 297 p.

BEAMISH, R. J.; MCFARLANE, G. A. The forgotten requirement for age validation in fisheries biology. Trans. Am. Fish. Soc., v. 112, n. 6, p. 735-743, 1983

BELLIDO, J. M.; PIERCE, G.J.; ROMERO, J.L.; MILLAN, M. Use of frequency analysis methods to estimate growth of anchovy (Engraulis encrasicolus L. 1758) in the Gulf of Cadiz (SW Spain). Fish. Res., v. 48, n. 2, p. $107-115,2000$

BERTALANFFY, L.V. Quantitative laws in the metabolism and growth. Q. Rev. Biol., v. 32, n. 3, p. 217-230, 1957.

BHATTACHARYA, C.G. A simple method of resolution of distribution into Gaussian components. Biometrics, v. 28, p. 115-135.

CADIMA, E. Manual de avaliação de recursos pesqueiros. Documento técnico sobre as pescas. FAO Fish. tech. Pap., v. 393, p. 10-125, 2000.

CAMPANA, S. E. Accuracy, precision and quality control in age determination, including a review on the use and abuse of age validation methods. J. Fish Biol., v. 59, 197-242, 2001.

CARDINALE, M.; HYELM, J. Marine fish recruitment variability and climate indices. Mar. Ecol. Progr. Ser., v. 309 , p. $307-309,2006$.

CARAMANTÍN, H. Efecto de la variabilidad ambiental en los aspectos reproductivos de la Caballa Scomber japonicus peruanus (Jordán y Hubb, 1925) en el litoral peruano durante 1990-1998. $136 \mathrm{p}$. 2001. Tese de maestría. Facultad de Ingenieria. Universidad Nacional Federico Villarreal de Lima, Perú, 2001.

CARAMANTÍN, H. Dinâmica populacional de Scomber japonicus peruanus (Jordán \& Hubb, 1925) (Teleostomi: Scombridae) no litoral peruano, no período de 1990 a 2003. 2006. 148 p. Tese de doutorado. Instituto Oceanográfico, Universidade de São Paulo, São Paulo, 2006.

CHIRICHIGNO, N.; VÉLEZ, J. Clave para identificar los peces marinos del Perú. Infmes Inst. Mar Peru, 1998. 496 p. (Edición especial).

CHOAT, J. H.; DAVIES, C. R.; ACKERMAN, J. L.; MAPSTONE, B. D. Age structure and growth in a large teleost Cheilinus undulates, with a review of size distribution in labrid fishes. Mar. Ecol. Progr. Ser., v. 318, p. 237-246, 2006.

CUCALON-ZENCK, E. Growth and length-weight parameters of Pacific mackerel (Scomber japonicus) in the Golf of Guayaquil. NAGA-ICLARM, v. 22, n.3, p. 32-36, 1999.

CUSHING, D.H. Climate and fisheries. London: Academic Press, $1982.373 \mathrm{p}$.

DAWSON, W. The interpretation of otolith structure for the assessment of age and growth of some pelagic fishes from the coast of Ecuador. Boln cient. tecn., Guayaquil, v. 9, n. $1,1986.24$ p.

DIOSES, T.; DÁVALOS, R.; ZUZUNAGA, J. El Niño $1982-$ 1983 and 1997-1998: Effects on Peruvian Jack mackerel and Peruvian Chub mackerel. Invest. mar., v. 30, n. 1, p. 185-187, 2002. 
DULCIC, J.; MATIC-SKOKO, S.; PALADIN, A.; KRALJEVIC, M. Age, growth, and mortality of brown comber, Serranus hepatus (Linnaeus, 1758) (Pisces: Serranidae), in the eastern Adriatic (Croatian coast). J. appl. Ichthyol., v. 23, n. 2, p . 195-197, 2007.

FAO. The State of World Fisheries and Aquaculture (SOFIA). Roma: Food and Agriculture Organization, 2007.162 P.

FREÓN, P.; MISUND, O. Dynamics of pelagic fish distribution and behaviour: effects on fisheries and stock assessment. London: Fishing New Books, 1999. $348 \mathrm{p}$.

FROESE, R.; PAULY, D. Fish Base 2000: concepts, design and data sources. Manila: ICLARM, 2000. $256 \mathrm{p}$.

GLUYAS-MILLÁN, M. G.; QUIÑONEZ-VELÁZQUEZ, C. Age, growth and reprodution of Pacific mackerel Scomber japonicus in the Gulf of California. Sci. Mar. v. 61, n. 3, p. 837-847, 1997.

HILBORN, R.; WALTERS, C. J. Quantitative fisheries stock assessment: choice, dynamics, and uncertainty. New York : Chapman and Hall, 1992. $570 \mathrm{p}$

HWANG, S. D.; LEE, T. W. Spawning dates and early growth of chub mackerel Scomber japonicus as indicated by otolith microstructure of juvenils in the inshore nursey ground. Fish Sci., v. 7, n. 2, p. 11851187, 2005.

IMARPE \& ITP. Compendio biológico tecnológico de las principales especies hidrobiológicas comerciales del Perú. Callao, 1996. p. 39-41.

IVERSEN, E. S. Living marine resources: their utilization and management, New York: Chapman \& Hall, 1996. $403 \mathrm{p}$.

KAMLER, E. Early life history of fish: an energetics approach. New York: Chapman \& Hall, 1992. 267 p. Fish and Fisheries Series.

KAMUKURU, A.T.; HECHT, T.; MGAYA, Y. D. Effects of exploitation on age, growth and mortality of the blackspot snapper, at Mafia Island, Tanzania. Fish. Mgmt Ecol., v. 12, p.45-55, 2005.

KIKKAWA, B. S.; CUSHING, J. W. Variations in the growth of bigeye tuna (Thunnus obesus) in the equatorial western Pacific Ocean. FOR DISCUSSION GROUP SUMMARIES, NSAW, Santa Cruz, California, December 11-13, 2001. [Abstr.].

KIPARISSIS, S.; TSERPES, G.; TSIMENIDIS, N. Aspects on the demography of Chub mackerel (Scomber japonicus Houttuyn, 1782) in the Hellenic seas. Belg. J. Zool., v. 130, p. 3-7, 2000.

LAPPALAINEN, J.; MALINEN, T.; NYBERG, K.; RAHIKAINEN, M.; RUUHIJARVI, J.; SALMINEN, M.; VINNI, K. Temperature dependent growth and yield of pikeperch, Sander lucioperca, in Finnish lakes. Fish. Mgmt Ecol., v. 12, p. 27-35, 2005.

MANCERA-RODRÍGUEZ, N.; CASTRO-HERNÁNDEZ, J. Age and growth of Stephanolepis hispidus (Linnaeus, 1766) (Pisces: Monacanthidae), in the Canary Islands area. Fish. Res., v. 66, p. 381-386, 2004.

MARTINEZ-PALACIOS, C.; CHAVEZ-SÁNCHEZ, M.C. ROSS, L.G. The effects of water temperature on food intake, growth and body composition of Cichlasoma urophathalmus (Gunther) juveniles. Aquat. J. Res., v. 27, p. 455-461, 1996.

MENDO, J. Edad, crecimiento y algunos aspectos reproductivos y alimenticios de la caballa, Scomber japonicus peruanus. Boln Inst. Mar Peru, v. 8, n. 4, p. 101-156, 1984.

MENZ, A.; PIZARRO, S. The fishery, biology and bionomic of the Pacific mackerel (Scomber japonicus) in Equator. INPE: Instituto Nacional de Pesca de Ecuador, Boln cient. tecn., Guaiaquil, v. 9, n. 10, p. 16-48., 1988.

MIÑANO, J.; CASTILLO, J. Primeros resultados de la investigación biologica pesquera de la "caballa" Scomber japonicus peruanus (Chimbote). Infmes Inst. Mar Peru, n. IM-84, 1971.

MORALES-NIN, B. Crecimiento de Scomber juponicus (Houttuyn, 1782) (Pisces: Scombridae) y Sardinops sugax (Jenyns, 1923) (Pisces: Clupeidae) en aguas ecuatorianas. Inv. pesq., v. 52, n. 4, p. 483-500, 1988

MOREAU, J.; BAMBINO, C.; PAULY, D. A comparison of four indices of overall growth performance based on 100 tilapia populations (Fam. Cichlidae). In: MACLEAN, J.L.; DIZON. L .B.; HOSILLOS, L.V. (Ed.). The first Asian fisheries forum. Asian Fish. Soc., 1986. p.201206.

MOREAU, J. Mathematical and biological expression of growth in fishes: recent trends and further developments. In: SUMMERFELT, R.C.; HALL, G.E. Age and growth of fish. Ames: Iowa State University Press, 1987. p. 81113.

ÑIQUEN, M.; BOUCHON, M. Impact of EL Niño of pelagic fisheries in Peruvian waters. Deep-Sea Res., Part. II, p. 51:563-574, 2004.

OLDEPESCA. Bases biológicas y marco conceptual para el manejo de los recursos pelágicos en el Pacífico Suroriental. Doc. Pesca, v. 1, 1986. 81 p.

PAJUELO, J. G.; LORENZO, J. M. Biology of the annular seabream, Diplodus annularis (Sparidae), in the coastal waters of the Canary Islands. J. appl. Ichthyol., v. 17, p. 121-125, 2001

PALOMARES, M.L.; MUCK, P.; MENDO, J.; CHUMAN, E.; GÓMEZ, O.; PAULY, D. Growth of the Peruvian anchoveta (Engraulis ringens), 1953 to 1982. In: PAULY, D. \& TSUKAYAMA, I. (Ed). The Peruvian anchoveta and its upwelling ecosystem: three decades of change. ICLARM: International Center for Living Aquatic Resources Management, 1987. $351 \mathrm{p}$.

PARRISH, R. H.; MALLICOTE, D. L.; MAIS, K. F. Regional variation in the growth and age composition of northern anchovy, Engraulis mordax. Fish. Bull., v. 83, n. 4, p. 483-496, 1985.

PAULY, D. Theory and management of tropical multispecies stocks: a review with emphasis on the Southeast Asian demersal fisheries. ICLARM: International Center for Living Aquatic Resources Management Stud. Rev., v. 1, 1979. $35 \mathrm{p}$.

PAULY, D. On the interrelationships between natural mortality, growth parameters, and mean environmental temperature in 175 fish stocks. J. Cons. Expl. Mar., v. 39, n. 2, p. 175-192, 1980.

PAULY, D.; GASCHUTZ, G. A simple method for fitting oscillating length grow data, with a program for pocket calculators. ICES: International Council for the exploration of the sea, CM 1979/G:24, 1979. $26 \mathrm{p}$. (Mimeo). 
PAULY, D.; TSUKAYAMA, I. On the seasonal growth, monthly recruitment and monthly biomass of Peruvian anchoveta (Engraulis ringens) from 1961 to 1979. In: SHARP, S.; CSIRKE, J. (Ed.). Proceedings of the expert consultation to examine changes in abundance and species composition of neritic fish resources, San José, Costa Rica, 18-29 April 1983. FAO Fish. Rep., v. 3, n. 291, p. 987-1004, 1983.

PAULY, D.; MUNRO, J. L. Once more on the comparison of growth in fish and invertebrates. ICLARM: International Center for Living Aquatic Resources Management, Fishbyte, v. 2, n. 1, p. 21, 1984.

PEREIRO, J. A. Verificación y extensión de la metodologia del análisis de distribuciones de tallas para la estimación de tasas instantáneas de mortalidad por pesca y de la producción por recluta de un stock explotado en estado de equilibrio. Inst. Esp. Oceanog., v. 10, 103 p., 1992. Edición especial.

PERROTA, R. G. Estudio biológico y pesquero de la caballa (Scomber japonicus Houttuyn, 1782). Mar Del Plata: INIDEP: Inst. Nacional Invest. Desarrollo Pesquero,v. 2, p.31-44, 1993

PERROTA, R.G.; VIÑAS, M.; HERNANDEZ, D. TRIGALI, L. Temperature conditions in the Argentine chub mackerel (Scomber japonicus) fishing ground: implications for fishery management. Fish. Oceanogr. v.10, n. 3, p. 275-283, 2001.

ROBARDS, M.; ROSE, G.; PLATT, J. Growth and abundance of Pacific sand lance, Ammodytes hexapterus, under differing oceanographic regimes. Environ. Biol. Fishes, v. 64, p. 429-441, 2002.
SANTANDER, H.; FLORES, R. Los desoves y distribución larval de cuatro especies pelágicas y sus relaciones con las variaciones del ambiente marino frente al Perú. FAO Fish. Rept.,v. 291, n. 3, p. 835-867, 1983.

SPARRE, P.; VENEMA, S. C. Introduction to tropical fish stock assessment. FAO Fish. tech. Pap., v. 306/1 (Rev. 2), 1997. $407 \mathrm{p}$.

SWAIN, D. P.; SINCLAIR, A. F.; CASTONGUAY, M.; CHOUINARD, G. A.; DRINKWATER, K. F.; FANNING, L. P.; CLARK, D. S. Density versus temperature-dependent growth of Atlantic cod (Gadus morhua) in the Gulf of St. Laurence and on the Scotian Shelf. Fish. Res., v. 59, n.3, p.327-341, 2003.

TAYLOR, C. C. Cod growth and temperature. J. Cons. int. Explor. Mer, v. 23, p. 366-370, 1958.

WANG, Y.; LIU, L. Estimation of natural mortality using statistical analysis of fisheries catch-at-age data. Fish. Res., v.78, p.342-351, 2006.

WILLIAMS, A. J.; MAPSTONE, B. D.; DAVIES, C. R. Spatial patterns in cohort-specific mortality of red throat emperor, Lethrinus miniatus, on the Great Barrier Reef. Fish. Res.,v. 84, n.3, p. 328-337, 2007.

(Manuscript received 18 June 2007; revised 04 September 2007; accepted 12 November 2007) 